\title{
Examination of Information System Design for Student's Scoring Processing
}

\author{
Suyatno, Phong Thanh Nguyen, A. Dinesh Kumar, R. Pandi Selvam, K. Shankar
}

\begin{abstract}
The development of information technology is needed in the education system to deal with various problems that arise in managing and solving problems that exist in educational institutions, especially in SMP PGRI 1 Semaka. The design of information processing systems for students uses web technology that can be used by teachers and employees to process student grades quickly and accurately and produce effective and correct information.

In designing this information system using an SDLC (Software Development Life Cycle) method. Whereas the programming language used uses PHP and Mysql as its database, xampp as a web server, and Mozilla Firefox as its web browser.
\end{abstract}

Keywords : information processing value system, web, SDLC.

\section{INTRODUCTION}

The development of information technology has reached almost all sectors [1]. This requires improving performance both in terms of effectiveness and efficiency [2]. One sector that becomes an important thing to note in performance improvement is in the education sector [3]. The development of information technology is needed in a quality education system in all fields, including in terms of educational material, teaching, testing, facilities and infrastructure [4].

Technology that develops at this time plays an important role in dealing with various problems that arise in managing and resolving problems that exist in educational institutions [5].

Data processing that is done manually requires a long time, so if it needs large data it is less efficient and requires a lot of time and energy [6].

Based on the description above, then the design of information systems processing students value in SMP PGRI 1 Semaka uses a web-based information technology so that it can be used to facilitate teachers and employees in processing the value of students quickly, accurately and effectively to produce the right information.

Revised Manuscript Received on July 22, 2019.

* Correspondence Author

Suyatno, Department of Information Systems, STMIK Pringsewu, Lampung, Indonesia.

Phong Thanh Nguyen*, Department of Project Management, Ho Chi Minh City Open University, Vietnam. E-mail: phong.nt@ou.edu.vn

A. Dinesh Kumar, Research Scholar, Department of Computer Applications, Alagappa University, Karaikudi, India. E-mail: dineshasoka661@gmail.com

R. Pandi Selvam, Assistant Professor and Head, PG Department of Computer Science, Ananda College, Devakottai, India. E-mail: pandiselvamraman@gmail.com

K. Shankar, Department of Computer Applications, Alagappa University, Karaikudi, India. E-mail: shankarcrypto@gmail.com

\subsection{Research Objectives and Significance of The Research}

The objectives to be achieved from this research are :

1. Applying and developing knowledge.

2. Making a design of information processing value systems

3. Finding and identifying the problems faced.

The significance of the research are :

1. As input material in processing the value data, to improve the quality of work quickly and accurately.

2. Extending knowledge and adding experience about how to design an information system.

\section{THEORITICAL FRAMEWORK}

\subsection{Definition of System Information}

Information system is a collection of hardware and software designed to transform data into useful information [7]. The information system is a system within an organization that brings the needs of daily transaction processing which supports the organization's operational functions that are managerial with strategic activities of an organization to be able to provide certain external parties with the necessary reports [8].

\subsection{Definition of Value System}

Information systems imply an organized data collection along with the procedures for its use which include more than just presentation [9].

\subsection{Definition of Website}

Website or often abbreviated as site, are several web pages that have interrelated topics, sometimes accompanied by images, videos, or other types of files [10].

A website is usually placed at least on a web server that can be accessed through networks such as the internet, or local area networks (LANs) through internet address that is recognized as a URL [11].

\subsection{Definition of PHP Dan MySQL}

\subsubsection{PHP}

PHP is a web programming language or scripting language designed to create web-based applications. PHP is the most widely used script programming language today. PHP is widely used to program dynamic websites, although it is not possible to use it for other uses.

\subsubsection{MySQL}

MySQL is a Relational Database Management System (RDBMS) that is distributed

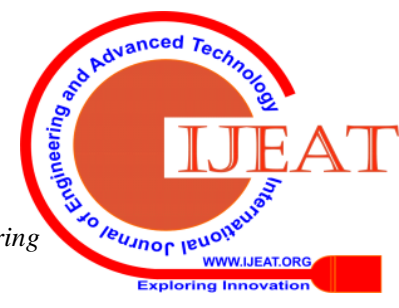


free under the GPL (General Public License). Where everyone is free to use MySQL, but may not be a commercial product. MySQL is a derivative of one of the main concepts in the database for a long time, namely SQL (Structured Query Language). SQL is a database operating concept, especially for data selection or input, which allows easy operation of data to be done automatically.

\subsection{SDLC Method}

SDLC is a step in developing information systems. SDLC provides a complete framework for form engineering activities and the development of formal information systems [11].

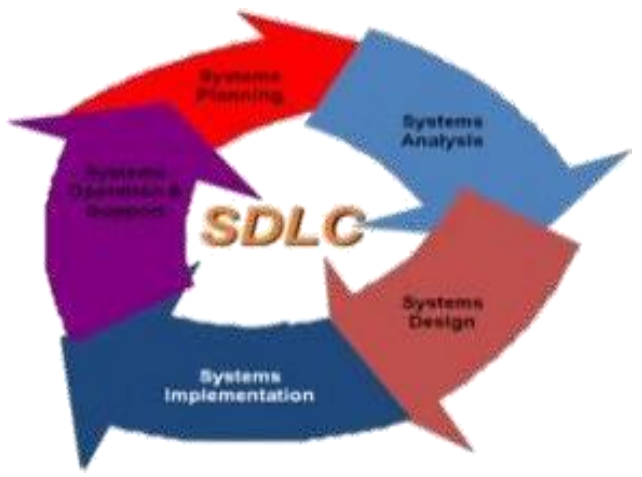

Figure 1: SDLC Method

Usually, the SDLC (System Development Life Cycle) method will focus on the methods and technicians used. SDLC stages in building a Web information system:

\section{Planning}

Planning is feasibility, interview, observation, and Questionaire. In this stage, the first thing to do is to provide a form to the user that is used to find out the user's request [12].

\section{Analysing}

Analysing is a stage of analyzing the needs of the user of the system to be made [13].

\section{Designing}

Designing is a stage of system design based on the analysis of needs that have been determined to be a system that will be applied [14].

\section{Coding}

Coding is the stage of making the system based on the analysis of needs and design that has been determined [15].

\section{Testing}

Testing is the stage after the application is completed. This stage serves to evaluate the application to ensure that the application is running [16].

6. Implementing

After the application is deemed appropriate and running, the application can already be applied and used by the user [17].

7. Maintenancing
Maintenancing is the stage of system maintenance and development [18].

\section{RESEARCH METHODOLOGY}

In designing this information system the researcher used the SDLC (Software Development Life Cycle) method. The stages were as follows:

a. Planning Stage

In this stage, the researcher recognized, defined the problem, determined the purpose of the system be made and identified the obstacles and conducted a feasibility study of the system design that will be created at SMP PGRI 1 Semaka [19].

\section{b. Analysing Stage}

In this stage, the researcher analyze the needs of the system to be designed and take into account the costs incurred by SMP PGRI and considered the risks that will occur with the existence of this information system [20].

c. Designing Stage

In this stage, the researcher designed page by page and determined the layout, colors, images, and databases that are expected to become an information system for SMP PGRI 1 Semaka that will be accessed by a user [21].

\section{d. Implementing Stage}

Writing and installing programs that have been analyzed and designed by using PHP and MySQL as well as testing the system that has been implemented with using a variety of existing browser technology and checking documents by following the design of the information system created [22].

\section{e. Maintenancing Stage}

In this stage, the researcher improved the errors that occur, modified, update, and developed the system and improved the performance of the system that has been designed [23].

\section{REQUIREMENTS ANALYSIS AND DESIGN}

\subsection{Hardware Requirements}

The following are hardware specifications used in building this information system:

- Processor : Intel Core 2 Duo

- Ram : $2046 \mathrm{MB}$

- Hard Disk : 2,00 GB

\subsection{Software Requirements}

The following are software specifications used in building this information system:

- Operating System : Windows XP/7

- Text Editor : Macromedia Dreamweaver 8

- Web Server : Xampp - Win32-1.7.0

- Database Server : MysQ1

- Web Browser :Mozila Firefox

- Drawing tool : Microsoft Visio 2007.

\subsection{Context Diagram}




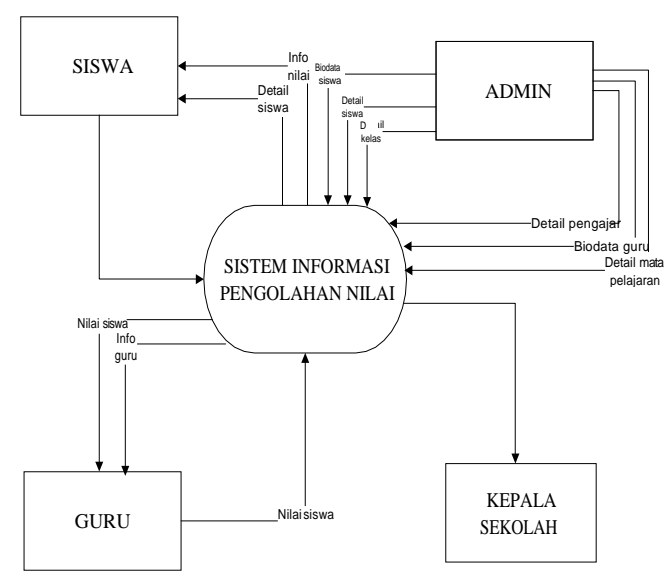

Figure 2: Context Diagram

\subsection{ERD (Entity Relationship Diagram)}

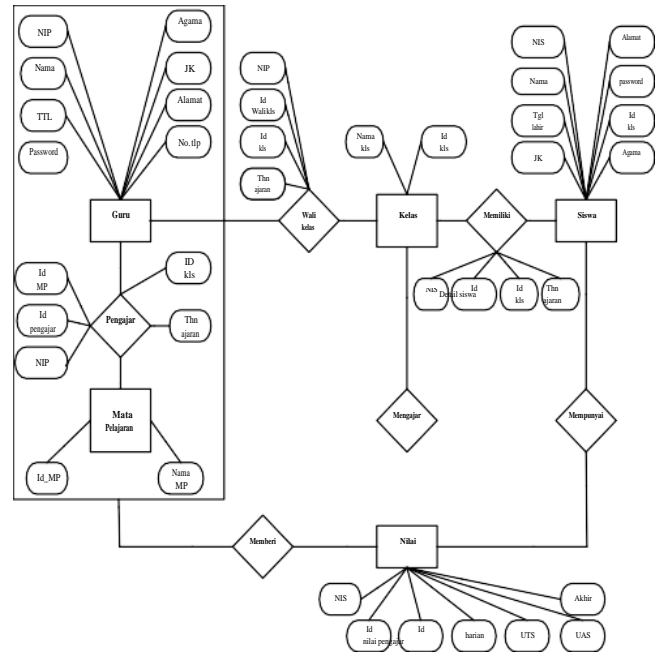

Figure 3: ERD

\subsection{Interface Design}

To complete the design it is necessary to describe how the input and output are displayed to facilitate the creation of views that will be created later.

\subsubsection{Main Page Screen Design}

Is a main page design in value proccessing information system at SMP PGRI 1 Semaka.

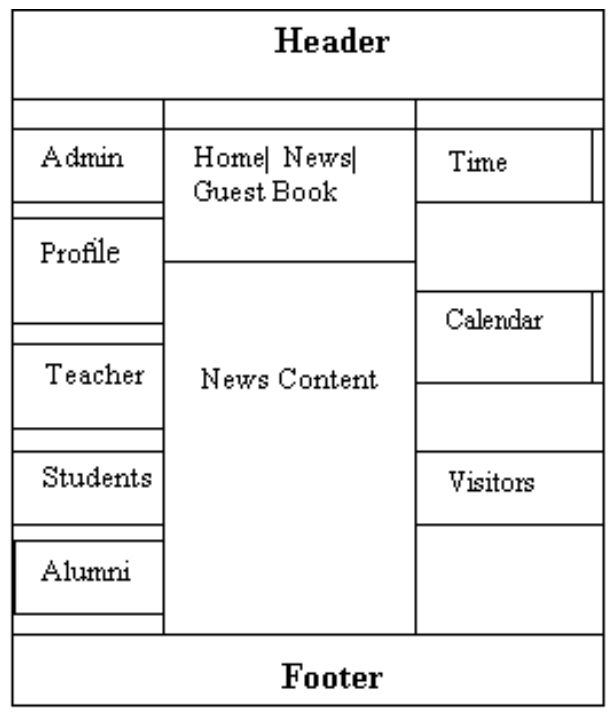

Figure 4: Main Page Screen

4.5.2 Students Input Screen Design

Explaining about students input screen design in value proccessing information system.

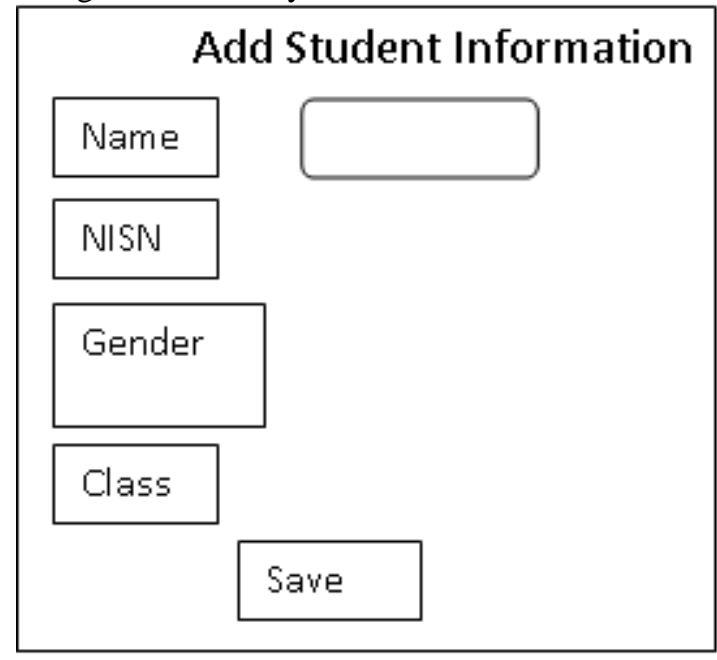

Figure 5: Students Input

\subsubsection{Admin Input Screen Design}

Explaining about admin input screen design in value proccessing information system.

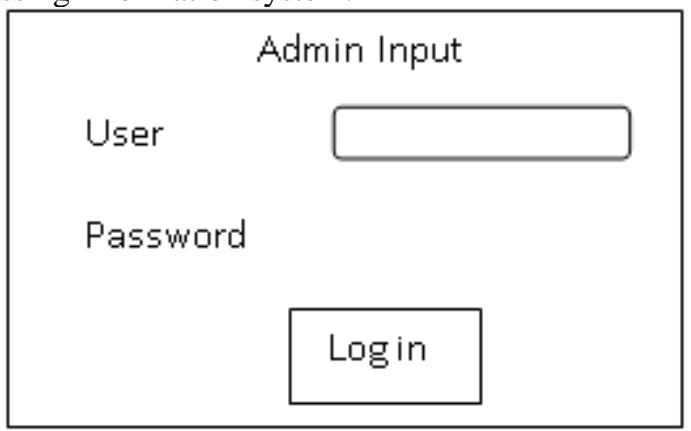

Figure 6: Admin Input Screen

\subsubsection{Guest Book Page Design}

Is a guest book page design for the visitors who want to give critism and suggestion.

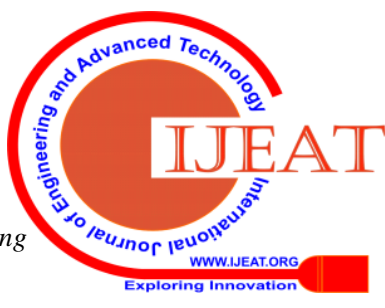




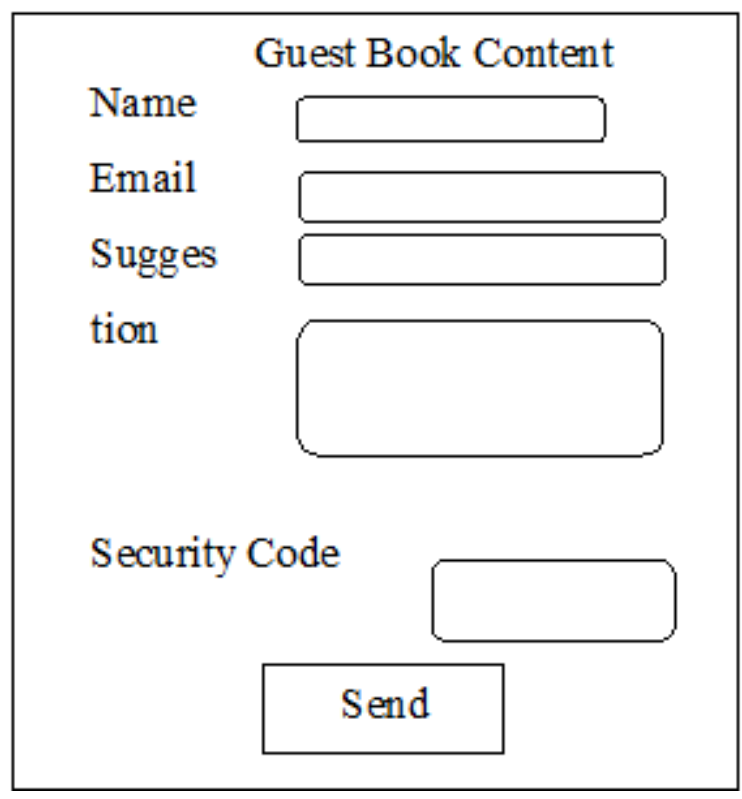

Figure 7: Guest Book Screen

\subsection{Display Screen of Program Implementation}

4.6.1 Main Page

The main page is designed in such a way as to provide convenience for website visitors so that the information presented by the school (admin) can be well received by website visitors. The design of the display is as follows:

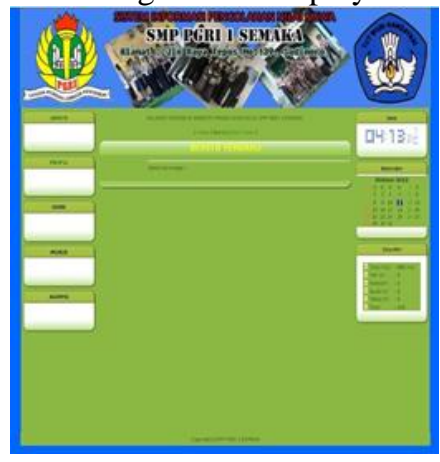

Figure 8 : Main Page

4.6.2 Students Input Page

This page is used to input the students data in value proccessing informaation system. The students input design is as follows:

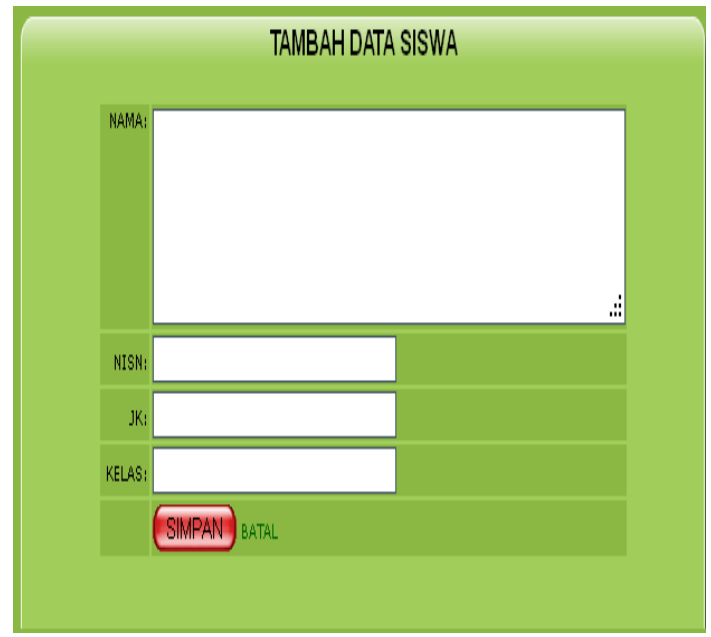

Figure 9: Students Input
4.6.3 Admin Page

Admin input page is the page that will be used to enter data about the admin or page to add a new admin. The admin input display design as follows:

\section{IHFTJT HDMIH}

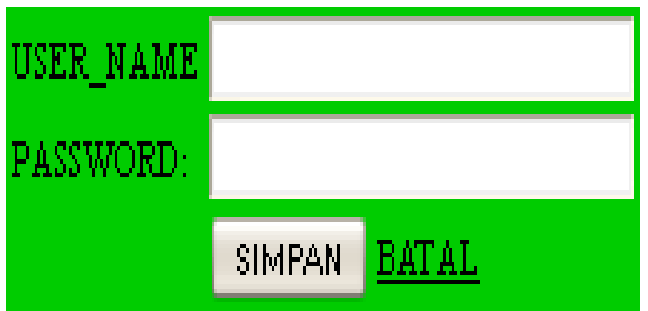

Figure 10: Admin Input

\subsubsection{Guest Book Page}

This page is used to display data on visitors to the PGRI 1 Semaka SMP website who have filled in the guest book and it is displayed on the website page. The design of the guest book list display as follows:

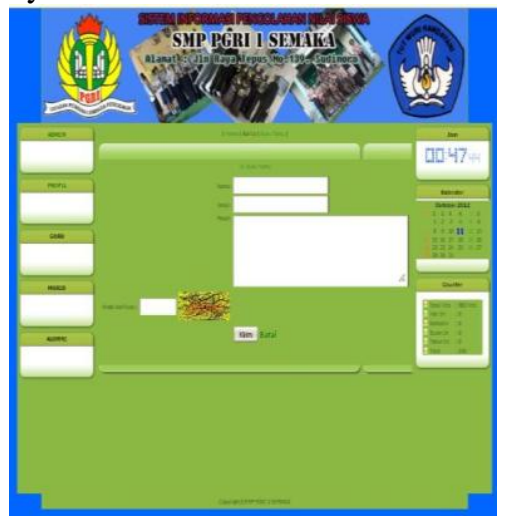

Figure 11: Guest Book Content

\section{CONCLUSION}

Analysis of the value proccessing information students design of PGRI 1 Semaka Middle School, it can be concluded that information technology is needed to process student grades quickly, effectively and accurately, to produce the correct information needed by the user. The information system can also make it easier for teachers and employees to process students' grades.

\section{REFERENCES}

1. Chienwattanasook, K., Wattanapongphasuk, W., Prianto, A., \& Jermsittiparsert, K. 2019. "Corporate Entrepreneurship and Business Performance of Logistic Companies in Indonesia." Industrial Engineering \& Management Systems 18 (3): 538-547.

2. Dawabsheh, M., Hussein, A., \& Jermsittiparsert, K. 2019. "The Triangular Relationship between TQM, Organizational Excellence and Organizational Performance: A Case of Arab American University Palestine.” Management Science Letters 9 (6): 921-932.

3. Jermsittiparsert, K., Siam, M., Issa, M., Ahmed, U., \& Pahi, M. 2019. "Do Consumers Expect Companies to Be Socially Responsible? The Impact of Corporate Social Responsibility on Buying Behavior." Uncertain Supply Chain Management 7 (4): 741-752. 
4. Syazali, M., Putra, F., Rinaldi, A., Utami, L., Widayanti, Umam, R., \& Jermsittiparsert, K. 2019. "Partial Correlation Analysis Using Multiple Linear Regression: Impact on Business Environment of Digital Marketing Interest in the Era of Industrial Revolution 4.0." Management Science Letters 9 (11): 1875-1886.

5. Sae-Lim, P. \& Jermsittiparsert, K. 2019. "Is the Fourth Industrial Revolution a Panacea? Risks toward the Fourth Industrial Revolution: Evidence in the Thai Economy.” International Journal of Innovation, Creativity and Change 5 (2): 732-752.

6. Maseleno, A., Hardaker, G., Sabani, N., \& Suhaili, N. (2016). Data on multicultural education and diagnostic information profiling: Culture, learning styles and creativity. Data in brief, 9, 1048.

7. Maseleno, A., Huda, M., Jasmi, K. A., Basiron, B., Mustari, I., Don, A. G., \& bin Ahmad, R. (2019). Hau-Kashyap approach for student's level of expertise. Egyptian Informatics Journal, 20(1), 27-32.

8. Maseleno, A., Huda, M., Siregar, M., Ahmad, R., Hehsan, A., Haron, Z., ... \& Jasmi, K. A. (2017). Combining the previous measure of evidence to educational entrance examination. Journal of Artificial Intelligence, 10(3), 85-90.

9. Chienwattanasook, K. \& Jermsittiparsert, K. 2019. "Impact of Entrepreneur Education on Entrepreneurial Self-Employment: A Case Study from Thailand." Polish Journal of Management Studies 19 (1): 106-116.

10. Jermsittiparsert, K., Sutduean, J., Sriyakul, T., \& Khumboon, R. 2019. "The Role of Customer Responsiveness in Improving the External Performance of an Agile Supply Chain.” Polish Journal of Management Studies 19 (2): 206-217.

11. Jermsittiparsert, K., Sutduean, J., \& Sriyakul, T. 2019. "Effect of Service Innovation and Market Intelligence on Supply Chain Performance in Indonesian Fishing Industry.” Industrial Engineering \& Management Systems 18 (3): 408-417.

12. Jermsittiparsert, K., Namdej, P., \& Somjai, S. 2019. "Green Supply Chain Practices and Sustainable Performance: Moderating Role of Total Quality Management Practices in Electronic Industry of Thailand.” International Journal of Supply Chain Management 8 (3): 33-46.

13. Somjai, S. \& Jermsittiparsert, K. 2019. "The Trade-off between Cost and Environmental Performance in the Presence of Sustainable Supply Chain." International Journal of Supply Chain Management 8 (4): 237-247.

14. Jermsittiparsert, K. \& Sawasdee, A. 2012. "Formal Education for Non-Thai or Undocumented Person in Thailand amidst the Challenge of Nationalism and Transnationalism: A Case Study of Wat Sirimongkhol School, Samut Sakhon Province." Kasetsart Journal Social Sciences 33 (2): 203-213.

15. Chatchawanchanchanakij, P., Arpornpisal, C., \& Jermsittiparsert, K. 2019. "The Role of Corporate Governance in Creating a Capable Supply Chain: A Case of Indonesian Tin Industry." International Journal of Supply Chain Management 8 (3): 854-864.

16. Hartinah, S., Suharso, P., Umam, R., Syazali, M., Lestari, B., Roslina, R., \& Jermsittiparsert, K. 2020. "Teacher's Performance Management: The Role of Principal's Leadership, Work Environment and Motivation in Tegal City, Indonesia." Management Science Letters 10 (1): 235-246.

17. Haseeb, M., Hussain, H., Slusarczyk, B., \& Jermsittiparsert, K. 2019 "Industry 4.0: A Solution towards Technology Challenges of Sustainable Business Performance." Social Sciences 8 (5): 184

18. Haseeb, M., Hussain, H., Kot, S., Androniceanu, A., \& Jermsittiparsert, K. 2019. "Role of Social and Technological Challenges in Achieving a Sustainable Competitive Advantage and Sustainable Business Performance." Sustainability 11 (14): 3811.

19. Haseeb, M., Kot, S., Hussain, H., \& Jermsittiparsert, K. 2019. "Impact of Economic Growth, Environmental Pollution, and Energy Consumption on Health Expenditure and R and D Expenditure of ASEAN Countries." Energies 12 (19): 3598.

20. Huda, S., Tsani, I., Syazali, M., Umam, R., \& Jermsittiparsert, K. 2020. "The Management of Educational System Using Three Law Auguste Comte: A Case of Islamic Schools." Management Science Letters 10 (3) (In press), DOI: 10.5267/j.msl.2019.9.018.

21. Usak, M., Kubiatko, M., Shabbir, M., Dudnik, O., Jermsittiparsert, K., \& Rajabion, L. 2019. "Health Care Service Delivery Based on the Internet of Things: A Systematic and Comprehensive Study." International Journal of Communication Systems 32 (14): e4179.

22. Jermsittiparsert, K., Ambarita, D., Mihardjo, L., \& Ghani, E. 2019. "Risk-Return through Financial Ratios as Determinants of Stock Price: A Study from ASEAN Region." Journal of Security and Sustainability Issues 9 (1): 199-210.
23. Thabhiranrak, T. \& Jermsittiparsert, K. 2019. "Towards Sustainable Functioning of Organization: Women Empowernment and Corporate Management Culture.” Journal of Security and Sustainability Issues 9 (1): 321-332. 